\section{THIS}

FEYNMAN Fifty years of those famous physics lectures and textbook $\mathbf{p . 8}$

\section{EDITORIALS}

WORLD VIEW A target of sexual harassment speaks out $\mathbf{p . 9}$

\title{
Call the cops
}

\section{The long arm of the law has reached into an investigation of alleged scientific misconduct in Italy, and should perhaps stretch still farther.}

S cience likes to shelter its crooks with euphemisms. The prefix 'research' softens fraud, and to deliberately obtain public money through deception gets labelled misconduct, among other things. This reflects the fact that the crime is viewed as being against professional standards rather than against the laws of wider society. The international game of science turned professional long ago, but the rules of play and their enforcement still harbour a decidedly amateur spirit.

Germany, for instance, lost its science-integrity innocence some 15 years ago when two high-flying biomedical researchers, Friedhelm Herrmann and Marion Brach, were found to have manipulated or fabricated data in 94 published papers. The affair - which became a world reference case for scientific fraud - shattered the complacency of German academia, which had never imagined that such bad conduct could occur in its world, and had no mechanism for dealing with it. In response, it established an admirable system of self-regulation, arming universities with clear guidelines on good scientific practice, procedures for investigating allegations of misconduct and an ombudsman system to which whistle-blowers can turn. It works well, if rather slowly.

Most scientifically ambitious countries now have similar systems in place, frequently rustled up in response to their own local scandals. The procedural details vary, but all the systems aim to protect the whistleblower and the accused during investigations and, crucially, carry out those investigations within the academic community. Self-regulation is written into the academic scriptures: what outsider could possibly understand the nuances of the scientific system, with its fundamental requirement for freedom of inquiry? But a case of alleged scientific misconduct currently under investigation in Italy begs a question, perhaps a heretical one: could the police sometimes do a better job at getting to the truth than the academic community?

Italy has no scientific-misconduct procedures in place, so last year, a frustrated whistle-blower presented his allegations of inappropriate duplication against a cancer researcher to the police (see page 18). The police seem to be carrying out a serious, detailed and thoroughly professional investigation. (No charges have been brought.)

Scientists, of course, should not have to live with the threat of being marched out of their lab in handcuffs whenever casual allegations are made. But, as the case in Italy shows, that is not how it has to work. The case is months from reaching a conclusion, but it is already clear that the procedures used by the police are no less protective of the parties involved than an academic inquiry would have been. Details were eventually leaked to the press, but only 20 months after the investigation began, and even then the whistle-blower was not exposed. The police are also at least as professional as academics, and, with their powers to confiscate computers and laboratory notebooks, can help the investigation to move forward more effectively. Academic investigators are often frustrated by accused scientists refusing to provide such evidence.

A natural response to a police investigation is that outsiders could never understand the academic system well enough to sit in judgement.

Really? Police forces worldwide routinely deal with financial and computer crimes, the details of which can seem equally impenetrable. Understanding what a western blot is and why it shouldn't be tampered with are obvious challenges for a non-scientist - as is understanding the mysteries of the academic world and the role of peer-reviewed publications within it. But the police know a thing or two about conducting an investigation. And any external inquiry has a distinct advantage: it

"Academic investigators could learn from police methods." cannot be hindered by the intrinsic threat of conflict of interest that comes when any community sits in judgement on its own members.

Admittedly, the learning curve for the Italian public prosecutors in this case has been extraordinarily steep. But the police can easily work out who should be called in to instruct them. In fact, they must be careful not to get things wrong, or they will be humiliated should a case reach court.

Science, of course, might not seem a top priority for law enforcers. And it is true that not all police departments would have the mindset to take fraud in arcane areas of science very seriously. Although much public money can be lost, fraudulent science must compete with more familiar crimes, such as tax evasion (and it pales in comparison with violent crimes).

Still, the Italian example does deserve broader discussion. At the very least, academic investigators could learn from police methods for dealing with allegations of serious misconduct - that word again. And researchers might be less tempted to be cavalier with the truth - and with our money - if they knew who else could knock on their door.

\section{The FDA and me}

\section{Medical testing firms find it is in their best interests to cooperate with regulators.}

$\mathrm{L}$ ate last month, US regulators dropped a bombshell on the genetic-testing start-up 23andMe in an exasperated cease-anddesist letter that prompted a fast and contrite response from the company - and a flurry of criticism of both parties among scientists and self-styled Health 2.0 activists who advocate the use of Internet tools in medicine.

Since 2007, 23andMe, which is based in Mountain View, California, has been testing customers' DNA for a range of traits, from the frivolous, such as earwax type, to the more significant, such as disease risk and genetic ancestry. The company has walked a fine line between promising that this activity will revolutionize medicine and averring 